\title{
PENYELENGGARAAN PERIZINAN DAN NON PERIZINAN DI KABUPATEN BEKASI
}

\author{
Waluyo Zulfikar ${ }^{1}$ \\ 1)Prodi Ilmu Administrasi Negara Universitas Nurtanio Bandung, Indonesia
}

\begin{abstract}
Abstrak
Permasalahan penyelenggaraan pelayanan perizinan dan non perizinan di Kabupaten Bekasi harus diselenggarakan secara baik kepada masyarakat. namun pada penerapannya, penyelenggaraan perizinan di Kabupaten Bekasi masih belum berjalan dengan baik, Kondisi tersebut justru menjauhkan konsep Perizinan dari konsep ideal, Aturan baku mengenai kelembagaan dan wewenang Dinas Penanaman Modal dan Pelayanan Terpadu Satu Pintu yang belum jelas menjadi pemicu berbagai permasalahan dalam proses pengurusan izin usaha yang ada di Kabupaten Bekasi. Peneliti melakukan analisis secara mendalam dengan menggunakan metode analisis deskriptif kualitatif dimana hasil penelitian ini menyimpulkan bahwa diperlukan upaya pembenahan dan perbaikan pelayanan perizinan dan non perizinan di Kabupaten Bekasi yang terbagi berdasarkan beberapa rangkaian prioritas pilihan. Penetapan prioritas pilihan berdasarkan parameter kedalaman upaya penyelesaian, lamanya waktu penanganan permasalahaan dan kesiapan SDM Pelaksana kebijakan, program dan kegiatan pemerintahaan yang ada di Kabupaten Bekasi. Kesalahan dalam penafsiran regulasi nasional terkait dengan kebijakan perizinan dan non perizinan akan berdampak pada ketidakjelasan terhadap fungsi dari adanya izin. Fungsi yang sama diatur dalam regulasi yang berbeda sehingga terjadi over regulated. Perlu pembenahan terhadap kebijakan perizinan dan non perizinan, dimana berdasarkan hasil kajian ini masih banyak izin yang terlahir karena diskresi pemerintah daerah, atau terlahir dalam praktek sehari-hari berpemerintahan.
\end{abstract}

Kata Kunci: Perizinan, Non Perizinan, Kabupaten Bekasi

\begin{abstract}
The problem of this research is explore licensing dan non-licecensing policy services in Bekasi Regency. That must be carried out properly to the community. but in practice, the implementation of licensing in Bekasi Regency is still not going well, this condition actually keeps the concept of licensing away from the ideal concept, standard rules regarding the institution and authority of the Investment Agency and One Stop Integrated Service which are not yet clear have triggered various problems in the permit processing process. existing businesses in Bekasi Regency. The researcher conducted an in-depth analysis using a qualitative descriptive analysis method where the results of this study concluded that efforts to improve and improve licensing and non-licensing services in Bekasi Regency were divided based on several series of priority choices. Determination of priority options based on parameters of depth of resolution efforts, length of time for problem handling and readiness of human resources executing policies, programs and government activities in Bekasi Regency. Errors in the interpretation of national regulations related to licensing and non-licensing policies will result in the unclear function of permits. The same function is regulated in different regulations so that it is over regulated. It is necessary to improve the licensing and nonlicensing policies, where based on the results of this study there are still many
\end{abstract}


permits that were born because of the discretion of the regional government, or were born in the daily practice of governing.

Keywords: Licensing, Non-Licensing, Bekasi Regency

\section{PENDAHULUAN}

\section{Latar Belakang}

Pelaksanaan otonomi daerah di Indonesia yang didasarkan pada UU No. 22 Tahun 1999 yang telah diubah menjadi UU No. 32 Tahun 2004 tentang Pemerintahan Daerah, pada tahun 2014 telah disempurnakan menjadi UU No. 23 Tahun 2014 dan disempurnakan kembali dengan UU No. 9 Tahun 2015. Hal ini merupakan landasan bagi pemerintah daerah dalam menjalankan roda pemerintahan di seluruh wilayah nusantara. Otonomi Daerah menciptakan ruang gerak yang lebih bebas dalam membuat kebijakan dan peraturan daerah yang melibatkan pihak-pihak terkait yang sesuai dengan pemahaman dan kebutuhan masyarakat masing-masing daerah tersebut. Dengan otonomi daerah diharapkan terjadi peningkatan pelayanan publik sekaligus memperbaiki kesejahteraan hidup masyarakat.

Pelaksanaan tata kelola pemerintahan yang baik (good governance) yang mulai banyak dilakukan oleh daerah-daerah saat ini tidak terlepas dari peluang yang diberikan oleh UU Otonomi Daerah tersebut. Prinsip-prinsip good governance yaitu transparansi, partisipasi, efisiensi dan efektivitas, akuntabilitas, keterbukaan, tatanan hukum yang baik (rule of law), ketanggapan, equity, dan visi strategis merupakan prinsip-prinsip yang harus dicapai dalam pelaksanaan good governance. Dari beberapa daerah yang telah lebih dahulu melaksanakan praktek-praktek tata kelola pemerintahan yang baik diperoleh hasil bahwa praktek-praktek good governance yang dilaksanakan secara nyata mampu menciptakan sistem pemerintahan yang lebih bersih dan akuntabel, sistem pelayanan kepada masyarakat yang lebih baik dan bahkan di beberapa daerah mampu meningkatkan kesejahteraan pegawai. 
Kondisi pelayanan publik di Indonesia masih diwarnai oleh prosedur yang berbelit-belit, akses yang sulit, biaya yang tidak transparan, waktu penyelesaian yang tidak jelas dan banyaknya praktek pungutan liar dan suap. Dengan otonomi daerah, sudah seharusnya pemerintah daerah lebih memperhatikan kualitas pelayanan publiknya. Bagi daerah yang sudah melaksanakan praktek-praktek tata kelola pemerintahan yang baik, pelayanan publik merupakan salah satu fokus perhatian pemerintah daerah.

Dalam praktek good governance, pelayanan publik perizinan dan non perizinan merupakan wujud pelayanan pemerintah daerah kepada masyarakatnya. Dalam hal ini birokrat pemerintah harus menunjukkan bahwa mereka adalah pelayan masyarakat sehingga masyarakat dalam melakukan urusannya merasa dilayani dan dipermudah. Masyarakat harus diberi kesempatan dan peluang untuk mendapatkan informasi yang benar dari pelayanan perijinan dan non perijinan yang diberikan. Oleh karena itu pemerintah daerah harus transparan dalam menginformasikan syarat, prosedur, biaya dan waktu penyelesaian setiap jenis perijinan dan non perijinan yang akan diurus oleh masyarakat.

Kabupaten Bekasi merupakan salah satu Kabupaten yang berdekatan dengan Ibukota Jakarta sebagai pusat pemerintahan nasional. Memiliki batas wilayah sebelah barat berbatasan langsung dengan Daerah Khusus Ibukota Jakarta dan Kota Bekasi, di wilayah utara berbatasan dengan laut Jawa, sebelah selatan berbatasan dengan kabupaten Bogor, sedangkan di wilayah Timur perbatasan Kabupaten bekasi adalah dengan Kabupaten Karawang. Kabupaten Bekasi memiliki letak geografis pada posisi 1060 48' 28” - 1070 27' 29” Bujur Timur dan 050 54' 50” - 060 29' 15" Lintang Selatan.Topografinya terbagi atas dua bagian yaitu dataran rendah yang meliputi sebagian wilayah bagian utara dan dataran bergelombang di wilayah bagian selatan, ketinggian lokasi terletak diantara 6 - 115 meter dan kemiringan 0-250 meter. Kabupaten Bekasi sebagai salah satu kabupaten bagian dari wilayah Provinsi Jawa Barat, secara administratif terdiri dari 23 Kecamatan, 5 Kelurahan dan 182 desadengan 
luas wilayah 127.388 Ha atau sebesar 3,43\% persen dari luas Provinsi Jawa Barat yang memiliki luas daratan 3.710.061,32 ha.

Kabupaten Bekasi merupakan daerah dengan kawasan industri terbesar di Asia Tenggara, dimana terdapat 16 kawasan industri dengan luasan lahan yang relatif besar. Selain itu, terdapat pula tujuh zona atau kawasan industri besar berskala internasional, sejalan dengan hal tersebut, permasalahan penyelenggaraan pelayanan publik di Pemerintah Daerah Kabupaten Bekasi harus diselenggarakan secara baik kepada masyarakat. Penyelenggaraan pelayanan perizinan secara terpadu di Kabupaten Bekasi secara kelembagaan sudah menjadi tugas pokok dan fungsi Dinas Penanaman Modal dan Pelayanan Terpadu Satu Pintu Kabupaten Bekasi, namun pada penerapannya, penyelenggaraan perizinan di Kabupaten Bekasi masih belum berjalan dengan baik, Dinas Penanaman Modal dan Pelayanan Terpadu Satu Pintu Kabupaten Bekasi saat ini hanya bertindak sebatas tempat penerimaan dokumen saja sedangkan proses pengurusan izin masih dikelola oleh masing-masing Perangkat Daerah Teknis. Kondisi tersebut justru menjauhkan konsep Perizinan dari konsep ideal, dimana seharusnya proses pengurusan perizinan sejak pengajuan berkas permohonan hingga penerbitan izin terintegrasi dalam satu lembaga yaitu Dinas Penanaman Modal dan Pelayanan Terpadu Satu Pintu. Aturan baku mengenai kelembagaan dan wewenang Dinas Penanaman Modal dan Pelayanan Terpadu Satu Pintu yang belum jelas menimbulkan berbagai permasalahan dalam proses pengurusan izin usaha.

Sejalan dengan dinamika pemerintahan yang terjadi, pengaturan penyelenggaraan pelayanan perizinan dan non perizinan di Kabupaten Bekasi didasarkan pada Peraturan Bupati Nomor 98 Tahun 2016 tentang Penyelenggaraan Pelayanan Perizinan, Nonperizinan dan Pelimpahan Kewenangan Untuk Menangani Sebagian Urusan Otonomi Daerah Di Kabupaten Bekasi. Sebagaimana telah diubah melalui Peraturan Bupati Nomo 35 Tahun 2017 tentang Penyelenggaraan Pelayanan Perizinan, Nonperizinan dan Pelimpahan Kewenangan Untuk Menangani Sebagian Urusan Otonomi Daerah Di Kabupaten Bekasi. Pada peraturan ini secara 
terang dibedakan antara perizinan dan nonperizinan untuk kelancaran penyelenggaraan pemerintahan sesuai dengan kebutuhan serta potensi daerah.

Secara eksisting Kabupaten Bekasi memiliki 191 jenis perizinan dan 74 jenis non perizinan yang tentunya menjadi objek Penelitian yang perlu dianalisa dalam penelitian ini. Adapun yang menjadi latar belakang masalah dalam pelaksanaan pekerjaan ini adalah pertama, Kabupaten Bekasi merupakan daerah industri yang memiliki industri terbanyak dibandingkan dengan kabupaten atau kota lainnya; kedua, permasalahan penyelenggaraan pelayanan publik di Pemerintah Daerah Kabupaten Bekasi harus diselenggarakan secara baik kepada masyarakat; ketiga, Penyelenggaraan pelayanan perizinan secara terpadu di Kabupaten Bekasi secara kelembagaan sudah menjadi tugas pokok dan fungsi Dinas Penanaman Modal dan Pelayanan Terpadu Satu Pintu Kabupaten Bekasi, namun pada penerapannya, penyelenggaraan perizinan di Kabupaten Bekasi masih belum berjalan dengan baik, Dinas Penanaman Modal dan Pelayanan Terpadu Satu Pintu Kabupaten Bekasi saat ini hanya bertindak sebatas tempat penerimaan dokumen saja sedangkan proses pengurusan izin masih dikelola oleh masing-masing Perangkat Daerah Teknis; Keempat, aturan baku mengenai kelembagaan dan wewenang Dinas Penanaman Modal. Karena itu Penelitian ini difokuskan mengenai Penelitian mengenai penyelenggaraan perizinan dan nonperizinan di Kabupaten Bekasi sesuai dengan peraturan perundang-undangan yang berlaku.

\section{Tujuan Penelitian}

Tujuan penelitian ini yaitu dapat memberikan gambaran Output/Keluaran Hasil Pemetaan Permasalahan Perizinan dan Non Perizinan yang sudah berjalan dan merumuskan langkah stategis yang akan dlaksanakan dalam Proses Integrasi Sistem Perizinan dan Non Perizinan di Kabupaten Bekasi sehingga Penyelenggaraan Perizinan di Kabupaten Bekasi berjalan secara ideal. 


\section{METODE PENELITIAN}

Metodologi yang akan digunakan untuk menganalisa permasalahan pelayanan perizinan dan non perizinan di Kabupaten Bekasi menggunakan pendekatan analisa deskriptif. Dilihat dari permasalahan yang menjadi fenomena dalam penelitian ini, dituntut untuk mampu merumuskan rekomendasi sebagai bahan penyusunan dokumen kebijakan dalam penyelenggaraan perizinan dan non perizinan di Kabupaten Bekasi. Diharapkan dengan pendekatan analisa deskriptif dapat melahirkan output Penelitian yang sesuai dengan tujuan penelitian.

\section{HASIL DAN PEMBAHASAN}

Sebagaimana tertuang didalam kerangka acuan kerja, Penelitian ini bertujuan untuk pemetaan permasalahan perizinan yang sudah berjalan dan mengambil langkah stategis yang akan dilaksanakan dalam proses integrasi sistem perizinan dan non perizinan di Kabupaten Bekasi, sehingga Penyelenggaraan Perizinan di Kabupaten Bekasi berjalan secara ideal sesuai dengan standar pelayanan publik dengan proses yang cepat, tepat dan biaya murah.

Dengan lahirnya Undang-Undang 23 Tahun 2014 tentang pemerintahaan daerah, sebagaimana telah dirubah beberapa kali, dan terakhir dengan Undang-Undang Nomor 9 Tahun 2015 tentang Perubahan Kedua Atas Undang-Undang Nomor 23 Tahun 2014 tentang Pemerintah Daerah mengarah pada efisiensi penyelenggaraan urusan pemerintahaan. Dengan lahirnya Undang-Undang 23 Tahun 2014 tentang Pemerintah Daerah berdampak pada pembagian kewenangan setiap urusan dan suburusan yang ada dalam penyelenggaraan kegiatan pemerintahan.

Penelitian ini menganalisa berbagai aspek yang ada kaitannya dengan pelayanan perizinan dan non perizinan di Kabupaten Bekasi. Analisa dilakukan secara mendalam dan menghasilkan deskripsi kondisi eksisting pelayanan perizinan dan non perizinan di Kabupaten Bekasi sebagaimana telah disampaikan pada bab-bab sebelumnya, Secara umum pelayanan 
perizinan dan non perizinan yang ada di Kabupaten Bekasi seluruhnya berjumlah 265 jenis, terdiri dari 191 izin dan 74 non perizinan. Tim menganalisa seluruh data yang ada, baik data primer maupun data sekunder dalam Penelitian ini. Data yang ada kemudian difilter berdasarkan urgensi dan tingkat relevansi terhadap kondisi eksisting fokus dan lokus Penelitian pelayanan perizinan dan non perizinan di Kabupaten Bekasi. Dengan menggunakan metode analisa deskriptif dan berbagai instrumen analisa kebijakan publik menghasilkan beragam parameter instrumen yang menjadi pisau analisa dalam Penelitian ini. Adapun simpulan didalam laporan antara ini yaitu sebagai berikut:

Tumpang tindih kebijakan dan aturan perundang-undangan yang ada di pemerintah pusat menimbulkan permasalahan tersendiri dalam ruang lingkup urusan pemerintahaan yang ada di Kabupaten Bekasi. Sejak diberlakukannya Undang-Undang Nomor 23 Tahun 2017 tentang Pemerintah Daerah sebagai pengganti Undang Undang No 32 Tahun 2004 berdampak pada banyaknya urusan pemerintahan di Kabupaten Bekasi yang harus dibenahi. Hal ini pula yang menyebabkan jumlah izin yang ada di Kabupaten Bekasi terus meningkat jumlahnya, sebagaimana dikemukakan di awal bahwa jumlah pelayanan perizinan dan non perizinan di Kabupaten bekasi seluruhnya berjumlah 191 izin dan 74 non perizinan. Banyak sekali aturan dan kebijakan pemerintah Kabupaten bekasi yang masih mengacu pada Kepada Peraturan perundang-undangan yang lama. Hal ini pada akhirnya berdampak pada banyaknya jumlah izin yang ada di Kabupaten Bekasi.

Berdasarkan analisa perbandingan pelayanan perizinan dan non perizinan di wilayah Provinsi Jawa Barat. Tim menganalisa berdasarkan banyaknya jumlah izin dan non perizinan yang ada di setiap kota/kabupaten yang ada di wilayah Provinsi Jawa Barat. Hasilnya, Kabupaten Bekasi menempati urutan teratas dengan jumlah jenis izin dan non perizinan seluruhnya yaitu 265 jenis izin. Disusul Kabupaten Bogor sejumlah 136 jenis perizinan, Kabupaten Karawang 131 jenis perizinan, Kabupaten Garut 128 jenis perizinan, Kabupaten Ciamis 109 jenis 
perizinan dan seterusnya. Kota Bekasi menempati jumlah paling sedikit untuk pelayanan perizinan yang dilayani yaitu hanya sejumlah 39 perizinan dan non perizinan.

Dengan adanya surat edaran menteri perdagangan tentang pencabutan izin HO. Berdasarkan Peraturan Menteri Dalam Negeri Republik Indonesia Nomor 19 Tahun 2017 Tentang Pencabutan Peraturan Menteri Dalam Negeri Nomor 27 Tahun 2009 Tentang Pedoman Penetapan Izin Gangguan Di Daerah Sebagaimana Telah Diubah Dengan Peraturan Menteri Dalam Negeri Republik Indonesia Nomor 22 Tahun 2016 Tentang Perubahan Atas Peraturan Menteri Dalam Negeri Nomor 27 Tahun 2009 Tentang Pedoman Penetapan Izin Gangguan Di Daerah. Pertimbangan Permendagri ini adalah bahwa Peraturan Menteri Dalam Negeri Nomor 27 Tahun 2009 tentang Pedoman Penetapan Izin Gangguan di Daerah sebagaimana telah diubah dengan Peraturan Menteri Dalam Negeri Republik Indonesia Nomor 22 Tahun 2016 tentang Perubahan atas Peraturan Menteri Dalam Negeri Nomor 27 Tahun 2009 tentang Pedoman Penetapan Izin Gangguan di Daerah sudah tidak sesuai dengan perkembangan keadaan, dan tuntutan kemudahan berusaha (ease of doing business) di Indonesia sehingga perlu dicabut. Dengan demikian disebutkan dalam Pasal 1 bahwa Pada saat Peraturan Menteri ini mulai berlaku, Peraturan Menteri Dalam Negeri Nomor 27 Tahun 2009 tentang Pedoman Penetapan Izin Gangguan di Daerah sebagaimana telah diubah dengan Peraturan Menteri Dalam Negeri Republik Indonesia Nomor 22 Tahun 2016 tentang Perubahan atas Peraturan Menteri Dalam Negeri Nomor 27 Tahun 2009 tentang Pedoman Penetapan Izin Gangguan di Daerah dicabut dan dinyatakan tidak berlaku.

Dengan adanya surat edaran menteri perdagangan tentang penghapusan perpanjangan SIUP. Menurut Permendag Nomor 07/MDAG/2/2017 bahwa dalam rangka mendukung kemudahan berusaha di bidang perdagangan, perlu menghapus kewajiban pendaftaran ulang surat izin usaha perdagangan sebagaimana diatur oleh Permendag No. 36/MDAG/Per/9/2007 tentang penerbitan surat izin usaha perdagangan 
sebagaimana telah beberapa kali diubah terakhir dengan Permendag No. 39/M-DAG/Per/12/2011 tentang perubahan kedua atas Permendag No 36/M-DAG/Per/2007 tentang Penerbitan Surat Izin Usaha Perdagangan.

Ketentuan Peraturan Menteri Perdagangan Nomor 07/MDAG/2/2017 mengatur pula bahwa SIUP berlaku selama perusahaan perdagangan menjalankan kegiatan usaha. Selain itu, dalam pasa 16 bahwa setiap perusahaan perdagangan yang mengajukan permohonan SIUP baru, perubahan dan / atau pergantian SIUP yang hilang atau rusak tidak dikenakan retribusi.

Dengan adanya surat edaran menteri perdagangan tentang penghapusan perpanjangan TDP. Berdasarkan Peraturan Menteri Perdagangan Nomor 08/M-DAG/Per/2/2017 perubahan kedua atas Permendag No. 37/M-DAG/Per/9/2007 tentang Penyelenggaraan Pendaftaran Perusahaan. Pertimbangan aturan ini yaitu dalam rangka mendukung kemudahan berusaha bagi pelaku usaha di bidang perdagangan, sehingga perlu mengubah beberapa ketentuan mengenai kewajiban pembaharuan Tanda Daftar Perusahaan. Di dalam Pasal 9a disebutkan bahwa 1) Bagi perusahaan yang akan memperbaharui TDP cukup menyampaikan surat pemberitahuan kepada kepala KKP Kabupaten/Kota/Kotamadya mengenai berakhirnya masa berlaku TDP dengan melampirkan TDP yang lama.2), Penyampaian surat pemberitahuan sebagaimana dimaksud pada ayat (1) dilakukan secara manual atau elektronik dengan format sebagaimana tercantum dalam lampiran VA yang merupakan bagian tak terpisahkan dari peraturan ini. 3) kepala KPP Kabupaten / Kota / Kotamadya menerbitkan TDP paling lambat 3 (tiga) hari kerja terhitung sejak diterimanya surat pemberitahuan pembaharuan TDP sebagaimana dimaksud pada ayat 1. 4), jangka waktu 3 (tiga) hari kerja pembaharuan TDP sebagaimana dimaksud pada ayat 3 tidak diterbitkan, maka TDP yang lama dianggap tetap berlaku dan sudah diperbaharui. 5), Pembaharuan TDP sebagaimana dimaksud pada (3) dikenakan biaya administrasi sebesar Rp.0,- (nol rupiah). 
Masih simpang siurnya pelayanan perizinan dan non perizinan yang ada di kabupaten bekasi berdampak pada menjamurnya "calo izin". Hal ini dikarenakan ketidakjelasan SOP karena sop perizinan yang ada sekarang masih menggunakan sop yang lama, sebagaimana SK kepala BPMPT nomor 503/kep/53-BPPT/2010 yang sudah tidak sesuai dengan kondisi pelayanan perizinan yanngg ada di bekasi. karena kebijakannya sudh banyak berubah. Terlebih dengan adanya peraturan kepala badan koordinsi penanaman modal nomor 15 tahun 2015 tentang pedoman dan tata cara perizinan dan non perizinan penanaman modal yang mengatur teknis dan prosedur pelayangn perizinan dan non perizinan.

Hasil analisa mendalam dari Penelitian ini, merekomendasikan penghapusan 19 jenis izin dan non perizinan yang tersebar pada 6 bidang urusan, yaitu: urusan Pendidikan, Kesehatan, Tenaga Kerja, Perhubungan, Penanaman Modal dan Pelayanan Terpadu Satu Pintu, Komunikasi, Informatika dan Persandian. Adapun jenis izin yang direkomendasikan untuk dihapus yaitu sebagai berikut: 1). Izin urusan pendidikan yang dihapuskan adalah Izin pendirian dan usulan penutupan Universitas / Institut / Sekolah tinggi dan Politeknik Negeri dan Swasta. 2), Izin urusan kesehatan yang dihapuskan adalah Izin Industri Farmasi, Izin perdagangan besar farmasi, Izin PBF Cabang, PBAK dan industri kecil obat tradisional (IKOT), Rekomendasi Izin sarana kesehatan tertentu yang diberikan oleh pemerintah dan provinsi, Rekomendasi hasil penelitian akreditasi. 3), Izin urusan tenaga kerja yang dihapuskan adalah Izin usaha perluasan kesempatan kerja Izin pelatihan sambil bekerja ke luar negeri, Perizinan penyelenggaraan pelatihan kerja dan sertifikasi kompetensi kerja, Perpanjangan izin penggunaan tenaga kerja warga negara asing pendatang (TKWNAP), Perpanjangan izin penggunaan tenaga kerja warga negara asing pendatang (TKWNAP). 4) Izin urusan perhubungan yang dihapuskan adalah Izin usaha bongkar muat dari dan ke apal, Izin usaha ekspedisi / freight forwarder. 5), izin urusan Penanaman Modal dan Pelayanan Terpadu Satu Pintu yang dihapuskan adalah Izin Bapel JPKM, Izin industri obat tradisional. 6), izin urusan Komunikasi, Informatika dan Persandian yang 
dihapuskan adalah Izin jasa titipan untuk kantor agen, Izin hinder dan ordonatie (ordonasi gangguan frekuensi), Izin penjualan laser disk VCD dan DVD, Izin usaha perdagangan alat perangkat telekomunikasi.

Izin yang direkomendasikan untuk digabungkan terdiri atas urusan Kesehatan, Tenaga Kerja, Perdagangan, Perindustrian. 1), Izin urusan Kesehatan yaitu Izin praktek perorangan dokter umum, Izin praktek perorangan dokter gigi, Izin praktek berkelompok dokter umum, Izin praktek berkelompok dokter gigi, Izin praktek bidan, Izin praktek perawat gigi, Izin praktek perorangan dokter spesialis, Izin praktek perorangan dokter gigi spesialis, Izin praktek berkelompok dokter spesialis, Izin praktek dokter gigi spesialis, Izin praktek tenaga kesehatan tertentu digabungkan menjadi Penerbitan izin praktik dan izin kerja tenaga kesehatan. Kemudian izin urusan Kesehatan lainnya yaitu Izin balai pengobatan, Izin rumah bersalin, Izin rumah sakit kelas $\mathrm{C}$ dan $\mathrm{D}$ dan fasilitas pelayanan kesehatan, Izin klinik Radiologi Swasta Perorangan, Izin Laboratorium Kesehatan, Izin klinik Fisioterapi digabungkan menjadi Izin Rumah Sakit kelas C dan D dan Fasilitas Pelayanan Kesehatan. Kemudian izin urusan Kesehatan lainnya yaitu Izin industri makanan dan minuman pada industri rumah tangga, Izin makanan serta minuman industri rumah tangga (PIRT) digabungkan menjadi Penerbitan izin industri makanan dan minuman pada industri rumah tangga. 2) Izin urusan Tenaga Kerja yang digabungkan yaitu Izin tempat penampungan TKI, Izin penampungan tenaga kerja indonesia digabungkan menjadi Izin penapungan tenaga kerja Indonesia. Kemudian izin urusan Tenaga Kerja lainnya yaitu Izin lembaga pelatihan kerja, Izin penempatan tenaga kerja, Izin pelatihan dan peningkatan produktifitas kerja, Izin LPK dan pelatihan lainnya yang non kurikulum Departemen Pendidikan, Izin dan pendaftaran lembga pelatihan, Izin lembaga pemagangan tenaga kerja Indonesia digabungkan menjadi Perizinan lembaga pelatihan kerja. Kemudian izin urusan Tenaga Kerja lainnya yaitu Izin bursa kerja khusus (BKK), Rekomendasi Kepada swasta dalam penyelenggaraan pemeran bursa kerja/job fair digabungkan menjadi Izin Bursa Kerja. Kemudian izin urusan Tenaga Kerja lainnya yaitu Izin 
operasional tenaga kerja sukarela (TKS) Luar negeri, TKS Indonesia, lembaga sukarela Indonesia, dan Rekomendasi izin operasional tenaga kerja sukarela (TKS) luar negeri, TKS Indonesia, lembaga sukarela indonesia digabungkan menjadi Izin operasional tenaga kerja sukarela (TKS). Kemudian izin urusan Tenaga Kerja lainnya yaitu Izin operasional perusahaan penyedia jasa pekerja/buruh, Pencabutan izin operasional perusahaan menyediakan jasa pekerja/buruh digabungkan menjadi Izin operasional perusahaan penyedia jasa pekerja/buruh. Kemudian izin urusan Tenaga Kerja lainnya yaitu Izin pendirian lembaga bursa kerja/LPTKS dan lembaga penyuluhan dan bimbingan, Rekomendasi untuk perizinan pendirian LPTKS dan lembaga penyuluhan dan serta bimbingan jabatan yang akan melakukan kegiatan dan Rekomendasi Lembaga penetapan tenaga kerja swasta digabungkan menjadi Penerbitan izin LPTKS dalam 1 (satu) Daerah Kabupaten/Kota. 3), Izin urusan Perdagangan yaitu Izin pengelolaan pasar Rakyat dan pusat perbelanjaan, Izin pengelolaan sampah pasar tradisional, Izin pemeliharaan prasarana dan sarana pasar dan kebersihan, Izin Guna Pakai bangunan di lingkungan pasar, Izin dan retribusi di bidang kebersihan pasar, Rekomendasi Penyelenggaraan parkir dan izin parkir didalam lingkungan pasar digabungkan menjadi Penerbitan izin pengelolaan pasar rakyat, pusat perbelanjaan dan izin toko swalayan. 4), Izin urusan Perindustrian yaitu Izin usaha Industri kecil dan Izin perluasannya, Izin Usaha Industri menengah dan izin perluasannya digabungkan menjadi Penerbitan IUI kecil dan IUI menengah.

Izin yang direkomendasikan untuk disederhanakan terdiri atas urusan Lingkungan Hidup, Perhubungan, Koperasi, Usaha Kecil dan Menengah, Perikanan dan Kelautan, Pertanian, Perdagangan, Komunikasi, Informatika dan Persandian. 1) Izin urusan Lingkungan Hidup yaitu Izin tempat pembuangan akhir sampah disederhanakan menjadi Penerbitan izin pendaur ulangan sampah/pengolahan sampah, pengangkutan sampah dan pemrosesan akhir sampah yang diselenggarakan oleh swasta. 2) izin urusan Perhubungan yaitu Izin usaha pembangunan pengoperasian pelabuhan pengumpan lokal disederhanakan menjadi Pembangunan, penerbitan izin 
pembangunan dan pengoperasian pelabuhan pengumpan lokal. Kemudian izin urusan Perhubungan lainnya yaitu Izin Usaha badan usaha disederhanakan menjadi Penerbitan izin usaha badan usaha pelabuhan di pelabuhan pengumpul lokal. Kemudian izin urusan Perhubungan lainnya yaitu Rekomendasi analisis dampak lalu lintas (ANDALLALIN) disederhanakan menjadi Persetujuan hasil analisis dampak lalu lintas untuk jalan Kabupaten/Kota. 2) Izin urusan Koperasi, Usaha Kecil dan Menengah yaitu Izin Bidang Koperasi, usaha kecil menengah dan fasilitas pembayaran serta simpan pinjam disederhanakan menjadi Penerbitan izin usaha simpan pinjam untuk koperasi dengan wilayah keanggotaan dalam Daerah Kabupaten/Kota. 3) Izin urusan Perikanan dan Kelautan yaitu Izin usaha budidaya ikan disederhanakan menjadi Penerbitan IUP di bidang pembudidayaan ikan yang usahanya dalam 1 (satu) Daerah Kabupaten/Kota. 4) Izin urusan Pertanian yaitu Izin Usaha Pertanian disederhanakan menjadi Penerbitan izin usaha pertanian yang kegiatan usahanya dalam Daerah Kabupaten/Kota. Kemudian izin urusan Pertanian lainnya yaitu Izin usaha produksi benih/bibit ternak dan pakan disederhanakan menjadi Izin usaha produksi benih/bibit ternak dan pakan, fasilitas pemeliharaan hewan, rumah sakit hewan/pasar hewan, rumah potong hewan. 5) Izin urusan Perdagangan yaitu Rekomendasi penerbitan tanda daftar gudang, dan surat keterangan penyimpanan baraang (SKPB) disederhanakan menjadi Penerbitan tanda daftar gudang. Kemudian izin urusan Perdagangan lainnya yaitu Penerbitan surat tanda pendaftaran waralaba (STVW) disederhanakan menjadi Penerbitan surat tanda pendaftaran waralaba (STPW) untuk penerima waralaba lanjutan dari waralaba luar negeri. 6) Izin Urusan Komunikasi, Informatika dan Persandian yaitu Pemberian Izin mendirikan bangunan (IMB) menara telekomunikasi sebagai sarana dan prasarana telekomunikasi disederhanakan menjadi Rekomendasi mendirikan bangunan menara telekomunikasi sebagai sarana dan prasarana telekomunikasi..

Izin yang direkomendasikan untuk dilimpahkan kewenangan penandatanganannya kepada sector urusan yang seharusnya sebagaimana 
amanah dari UU Nomor 23 Tahun 2014 tentang Pemerintah Daerah terdiri atas izin urusan Penanaman Modal dan Pelayanan Terpadu Satu Pintu yaitu Izin Pembuangan Limbah Cair (IPLC) masuk pada sektor lingkungan hidup dalam izin pembuangan dan pemanfaatan limbah cair, Izin Praktek Dokter Hewan masuk pada sektor kesehatan dalam Penerbitan izin praktik dan izin kerja tenaga kesehatan, Izin Pendirian Sekolah masuk pada sektor pendidikan, Izin perparkiran diluar badan jalan masuk pada sektor perhubungan dalam izin Penyelenggaraan dan Pembangunan Fasilitas Parkir, Izin pendidikan dan latihan luar sekolah masuk pada sektor pendidikan dalam penerbitan izin pendidikan anak usia dini dan pendidikan non formal yang diselenggarakan oleh masyarakat, Izin Pengelolaan air kotor dan Lumpur tinja masuk pada sektor lingkungan hidup, Izin Optical dan Izin Toko Obat masuk pada sektor kesehatan dalam izin Apotik dan Toko Obat. Toko alat kesehatan dan optikal, Izin toko swalayan masuk pada sektor perdagangan dalam Penerbitan izin pasar rakyat, pusat perbelanjaan dan izin toko swalayan, dan Izin usaha perdagangan minuman berarkohol golongan $\mathrm{B}$ dan $\mathrm{C}$ untuk pengecer/penjual langsung minum ditempat masuk pada sektor perdagangan.

Izin yang tetap dan tidak direkomendasikan untuk dirubah mencakup beberapa izin urusan Kesehatan, Pekerjaan Umum dan Penataan Ruang, Sosial, Tenaga Kerja, Perumahan Rakyat, Kawasan Permukiman dan Pertanahan, Lingkungan Hidup, Perhubungan, Penanaman Modal dan Pelayanan Terpadu Satu Pintu, Arsip dan Perpustakaan, Pertanian, Perdagangan, Komunikasi, Informatika dan Persandian, Parawisata, Pemadam Kebakaran. Beberapa izin mencakup urusan tersebut adalah tetap dan sesuai dengan Peraturan Bubati No. 35 Tahun 2017 dan Masih Relevan Dengan UU 23 Tahun 2014 serta Peraturan Perundang-Undangan Lainnya.

Potensi izin baru yaitu berdasarkan kondisi dilapangan dan perbandingan kebijakan pelayanan perizinan dan non perizinan yang ada di Kabupaten Bekasi, tim mendapatkan perizinan yang belum 
dimunculkan/belum ada di Kabupaten Bekasi dan izin yang direkomendasikan untuk dilimpahkan kewenangan penandatanganannya berdasarkan Perspektif UU 23 Tahun 2014, hal ini bisa digunakan sebagai acuan untuk mendapatkan potensi izin baru bagi sektor urusan perizinan dan non perizinan yang ada di Kabupaten Bekasi. Perizinan dan non perizinan sebagai potensi izin baru ini mencakup beberapa uruusan yaitu urusan Pendidikan, Kesehatan, Pekerjaan Umum dan Penataan Ruang, Sosial, Tenaga Kerja, urusan Perumahan Rakyat, Kawasan Permukiman dan Pertanahan, urusan Lingkungan Hidup, Perhubungan, urusan Koperasi, Usaha Kecil dan Menengah, urusan Kebudayaan, urusan Energi dan Sumber Daya Mineral, Perdagangan, dan urusan Perindustrian. Potensi izin sebagai rekomendasi untuk setiap urusan tersebut adalah 1) Izin urusan Pendidikan yaitu Penerbitan izin pendidikan dasar yang diselenggarakan oleh masyarakat, dan Penerbitan izin pendidikan anak usia dini dan pendidikan non formal yang diselenggarakan oleh masyarakat. 2) Izin urusan Kesehatan yaitu Penerbitan izin usaha mikro obat tradisional (UMOT), Penerbitan sertifikat produksi alat kesehatan kelas 1 (satu) tertentu, dan Penerbitan sertifikat perbekalan kesehatan rumah tangga (PKRT) kelas 1 (satu) tertentu perusahaan rumah tangga. 3) Izin urusan Pekerjaan Umum dan Penataan Ruang yaitu Penerbitan izin pembangunan dan pengembangan perumahan, Penerbitan sertifikat kepemilikan bangunan gedung (SKBG), dan Penerbitan izin pembangunan dan pengembangan kawasan permukiman. 4) Izin urusan Sosial yaitu Penerbitan izin pengumpulan sumbangan dalam Daerah kabupaten/kota. 5) Izin urusan Tenaga Kerja yaitu

Pendaftaran lembaga pelatihan kerja, Pengesahan peraturan perusahaan dan pendaftaran perjanjian kerja bersama untuk perusahaan yang hanya beroperasi dalam 1 (satu ) Daerah kabupaten/kota. 6) Izin urusan Perumahan Rakyat, Kawasan Permukiman dan Pertanahan yaitu Pemberian izin lokasi dalam 1 (satu) Daerah kabupaten/kota, dan Penerbitan izin membuka tanah. 7) Izin urusan Lingkungan Hidup yaitu Izin Pengelolaan air kotor dan Lumpur tinja 8) Izin urusan Perhubungan 
yaitu Penerbitan izin pengembangan pelabuhan untuk pelabuhan pengumpan lokal, Penerbitan izin pengoperasian pelabuhan selama 24 jam untuk pelabuhan pengumpan lokal, Penerbitan izin pengelolaan Terminal Untuk Kepentingan Sendiri (TUKS) di dalam DLKR/DLKP pelabuhan pengumpan lokal. 9) Izin urusan Koperasi, Usaha Kecil dan Menengah yaitu Penerbitan izin pembukaan kantor cabang, cabang pembantu dan kantor kas koperasi simpan pinjam untuk koperasi dengan wilayah keanggotaan dalam Daerah kabupaten/kota. 10) Izin urusan Kebudayaan yaitu Penerbitan izin membawa cagar budaya ke luar Daerah kabupaten/kota dalam 1 (satu) Daerah provinsi. 11) Izin urusan Energi dan Sumber Daya Mineral yaitu Penerbitan izin pemanfaatan langsung panas bumi dalam Daerah kabupaten/kota. 12) Izin urusan Perdagangan yaitu Rekomendasi penerbitan PKAPT (Pedagang Kayu Antar Pulau Terdaftar ) dan pelaporan rekapitulasi perdagangan kayu atau pulau, Penerbitan surat keterangan penyimpanan barang (SKPB), Penerbitan surat tanda pendaftaran waralaba (STPW) untuk penerima waralaba lanjutan dari warlaba dalam negeri Penerbitan surat tanda pendaftaran waralaba (STPW) untuk penerima waralaba lanjutan dari waralaba luar negeri, Penerbitan surat keterangan asal (bagi Daerah kabupaten/kota yang telah ditetapkan sebagai instansi penerbit surat keterangan asal), dan Izin usaha perdagangan minuman berarkohol golongan B dan C untuk pengecer/penjual langsung minum ditempat Izin urusan Perindustrian yaitu Penerbitan IUKI dan IPKI yang lokasinya di Daerah kabupaten/kota, dan Penerbitan IPUI bagi industri kecil dan menengah.

Pemanfaatan, pengembangan dan penguasaan teknologi bagi pelaksana pemberian izin dan non perizinan di Kabupaten Bekasi dalam belum sepenuhnya memenuhi azas pelayanan perizinan yang mudah, cepat, tepat, akurat, transparan dan akuntabel. Permasalahan ini utamanya bersumber pada kualitas sumber daya manusia yang masih rendah, lingkungan yang belum kondusif untuk tumbuh berkembangnya kemampuan iptek daerah yang terkait dengan belum kuatnya kelembagaan dan kebijaksanaan operasional iptek di daerah. Selain itu, salah satu 
prasarana yang memerlukan pengelolaan dan manajemen yang baik adalah media pelayanan. Media pelayanan yang baik diantaranya pelayanan yang berbasis teknologi secara online melalui teknologi internet. Selama ini pengajuan perizinan dan non perizinan hanya sebagian yang mampu dilayani secara elektronik. Teknologi yang dapat digunakan untuk memberikan pelayanan publik adalah e-mail, WAN (Wide Area Network), internet, mobile computing (HP, laptop, android) di Kabupaten Bekasi belum dikelola secara optimal. Sehingga pada penyelenggaraan pelayanan perizinan dan nonperizinan cenderung masih manual. Padahal kekuatan teknologi informasi sangat penting karena harus sejalan dengan perkembangan teknologi dan kebudayaan masyarakat.

Selain kekuatan teknologi juga kesiapan manusianya atau pegawai sangat penting dalam pembangunan teknologi informasi di Kabupaten Bekasi. Dengan kata lain di era teknologi informasi pembangunan pada penyelenggaraan perizinan dan nonperizinan harus ditunjang oleh kekuatan sumber daya manusia. Dengan demikian, adanya peningkatan Sumber Daya Manusia perlu dilakukan melalui upaya meningkatkan kompetensi (Kompetensi teknis, Kompetensi konseptual, kemampuan untuk beriteraksi secara afektif), mengembangkan kreatifitas dan inovasi, mendayagunakan modal intelektual Sebagai kekayaan organisasi dan mengantisipasi kompetensi global dengan membangun sikap kompetitif, berarti membangun sumber daya manusia handal, memiliki wawasan luas, dan sekaligus "concern" terhadap kemajuan tekologi informasi.

Reformasi birokrasi dalam konteks pelayanan perizinan dan non perizinan di Kabupaten Bekasi mengisyaratkan bahwa bagaimana pelayanan publik yang bersih dan bertanggung jawab menjadi sebuah keharusan. Masih banyaknya aktivitas "calo izin" secara tidak langsung menjadi kendala dalam menjalankan konsep good governace di Kabupaten Bekasi. Tanpa sengaja dalam pelaksanaan Penelitian ini, bersamaan dengan terjadinya oprasi tangkap tangan di DBMPTSP Kabupaten Bekasi. Hal ini diharapkan dapat menjadi gambaran untuk perbaikan pelayanan perizinan dan Non Perizinan di Kabupaten Bekasi. 


\section{KESIMPULAN (Bookman Old Style 12 dicetak tebal)}

Sebagaimana telah dijabarkan dalam kesimpulan dari kajian ini, beragam permasalahaan timbul dalam penyelenggaraan pelayanan perizinan dan nonperizinan di Kabupaten Bekasi. Adapun upaya yang dapat dilakukan dalam rangka pembenahan dan perbaikan pelayanan perizinan dan non perizinan di Kabupaten Bekasi dibagi berdasarkan beberapa rangkaian prioritas pilihan. Penetapan prioritas pilihan berdasarkan parameter kedalaman upaya penyelesaian, lamanya waktu penanganan permasalahaan dan kesiapan SDM Pelaksana kebijakan, program dan kegiatan pemerintahaan yang ada di Kabupaten Bekasi. Sebagaimana telah disampaikan sebelumnya, sumber utama permasalahan pelayanan perizinan dan non perizinan di daerah, khususnya di Kabupaten Bekasi adalah tumpang tindihnya regulasi nasional. Kesalahan dalam penafsiran regulasi nasional kebijakan perizinan dan non perizinan akan berdampak terhadap ketidakjelasan terhadap fungsi dari adanya izin. Fungsi yang sama diatur dalam regulasi yang berbeda sehingga terjadi over regulated. Perlu pembenahan terhadap kebijakan perizinan dan non perizinan, dimana berdasarkan hasil kajian ini masih banyak izin yang terlahir karena diskresi pemerintah daerah, atau terlahir dalam praktek sehari-hari berpemerintahan. Sebagai akibatnya masih ada izin yang belum diatur didalam Peraturan Daerah (hanya diatur didalam peraturan bupati). Padahal sarat sahnya satu izin adalah jaminan kepastian hukum dan pemenuhan terhadap azas-azas pemerintahan yang baik. Metoda HGSLTT (Hapus, Gabung, Sederhanakan, Limpahkan, Tetap \& Tambahkan) dirasa akan sangat ampuh sebagai bagian dari upaya pembenahan pelayanan perizinan dan non perizinan di Kabupaten Bekasi.

\section{DAFTAR PUSTAKA}

Abdul Wahab, Solichin. 2008. Analisis Kebijaksaan dari formulasi ke implementasi kebijaksanaan negara. Jakarta : Bumi Aksara 
Akadun.2009.Teknologi Informasi Administrasi.Bandung: Alfabeta

Albrow, Martin, 1996, Alih Bahasa: M. Rusli Karim dan Totok Daryanto. Birokrasi, Yogyakarta: PT. Tiara Wacana

Afadlal (edit), 2003. Dinamika Birokrasi Lokal Era Otonomi Daerah, Jakarta: Lipi

Azizy, A Qodri, 2007, Change Management dalam Reformasi Birokrasi, Jakarta: PT. Gramedia Pustaka Utama

Blau, M. Peter. Marshall W. Meyer, 2000, Alih Bahasa: Slamet Rijanto: Birokrasi Dalam Masyarakat Modern. Jakarta: Prestasi Pustakarya Pustaka Utama

Djatmiko, Yayat Hayati, 2008, Perilaku Organisasi, Bandung: Alfabeta

Dunn, William N, 2000. Pengantar Analisis Kebijakan Publik. Yogyakarta. Gajah Mada University Press.

, 2008. Mewujudkan Good Governance Melalui Pelayanan Publik. Yogyakarta: Gadjah Mada University Press

irmanzah, 2008, Mengelolah Partai Politik, Komonikasi dan Positioning ideology politik di Era Demokrasi. Jakarta:Yayasan Obor Indonesia

Garna, Judistira K, 2000, Metode Penelitian Sosial, Penelitian dalam Ilmu Pemerintahan, Bandung: Primaco Akademika

Gulo, W, 2010, Metodologi Penelitian , Jakarta: Grasindo

--------,2005, Benturan Antar Peradaban dan Masa Depan Politik Dunia, Yogyakarta: CV. Qalam

Hoogerwerf, A, 1983, Ilmu Pemerintahan. Jakarta: Erlangga

Kantraprawira, Rusadi, 1983, Sistem Politik Indonesia: Suatu Model Pengantar, Bandung: PT. Sinar Baru

Ketchum, Richard M (ED), 2004. Demokrasi Sebuah Pengantar. Yogyakarta: Niagara

Latunreng, Wahyudin, 2007. Budaya Organisasi, Jakarta: IPPSDM-WIN

Ndraha, Taliziduhu, 2006, Kybernologi: Sebuah Scientific Enterprise, Tangerang Banten: Sirao Crenditia Center

-------- , 1988, Metodologi Pemerintahan Indonesia, Jakarta: Bina Aksara ,2007, Kybernologi Sebuah Scientific Movement, Jakarta: IIP

,2005, Kybernologi. Beberapa Konstruksi Utama, Tangerang Banten: Sirao Credentia Center 
------- ,2003, Kybernologi Sebuah Charta Pembaharuan, Tangerang Banten: Sirao Credentia Center

Pasolong, Harbani, 2008, Kepemimpinan Birokrasi, Bandung: Alfabeta

Rasyid, M. Ryaas, 1999, Kajian Awal Birokrasi Pemerintahan dan politik Orde Baru, Jakarta: MIPI dan Yarsif Watampone

-----------, 2000. Makna Pemerintahan- Tinjauan dari segi Etika dan Kepemimpinan, Jakarta: Mutiara Sumber Widya

Ripley, Randall, B, Franklin , Grace, A, Policy Implementation and Bureaucrcy (second edition). Chicago, Illionis: The Dorsey Press

Sharma, P, 2004. Sistem Demokrasi yang Hakiki. Jakarta: Yayasan Menera Ilmu.

Siagian, Sondang P, 1994, Patologi Birokrasi. Analisis, Identifikasi dan Terapinya, Jakarta: Ghalia Indonesia

2008, Administrasi Pembangunan, Konsep, Dimensi dan strateginya. Jakarta: Bumi Akasara

--------- , 2008, Manajemen Sumber Daya Manusia, Jakarta: Bumi Aksara

Sudardi, Konsep dan Materi Dari Segi Hukum Tata Negara Untuk Naskah Akademik RUU tentang Administrasi Pemerintahan, Semiloka I kajian Reformasi Hukum Administrasi Pemerintahan, Kementrian PAN,27-28 April 2017.

Sorensen, Georg, 2003, Demokrasi dan Demokratisasi. Proses dan Prospek dalam sebuah dunia yang sedang berubah, Yogyakarta: Pustaka Pelajar

Thoha, Miftah, 2005, Birokrasi dan Politik di Indonesia, Jakarta: Rajawali Pers

----- ,2008, Birokrasi Pemerintah Indonesia di Era Reformasi, Jakarta: Kencana Prenada Media Group

------, 2008, Ilmu Administrasi Publik Kontemporer, Jakarta: Kencana Prenada Media Group

------, 1998. Birokrasi Indonesia Dalam Era Globalisasi. Jakarta: Batang Gadis

------, 1996. Pembinaan Organisasi; Proses Dianosa dan Intervensi. Jakarta: Raja Grafindo Persada

Tjiptono, Fandy, 1997, Prinsip-Prinsip Total Quality Service, Yogyakarta: Andi

Wibawa, Samodra, 2011, Politik Perumusan Kebijakan Publik, Yogyakarta: Graha Ilmu 
ibawa Samodra.2014.Noto Negoro 1 Panduan Mengelola Negara

Wilson, James Q, 1989. Bureaucracy What Government Agencies Do and Why They Do It, Basic Book: United States of America

Winardi, J, 2000, Kepemimpinan dalam Manajemen, Jakarta: Rineka Cipta

, 2003, Teori Organisasi dan Pengorganisasian, Jakarta: Raja Grafindo Persada

Wexley, Kenneth N dan Gary A. Yuki, 2005. Perilaku Organisasi dan Psikologi Personalia, Jakarta: PT. Rineka Cipta

Yukl, Gary, 2001, Kepemimpinan Dalam Organisasi, Jakarta: Indeks

Zeithaml, Valerie A, A. Parasuraman and Mary Jo Bitner, 2000. Service Marketing, New York: McGraw-Hill International Editions

A. Parasuraman And L.L. Berry, 1996. Delivering Quality, New York: The Free Press

A. Parasuraman, Berry and Leonardo L, 1990. Delivering Quality Service: Balancing Customer Perceptions and Expectations. The Free Press: Adivision of Macmillan, Inc

Zuhro, R,Siti dkk, 2009, Demokrasi Lokal, Perubahan dan Kesinambungan Nilai-nilai Politik Lokal di Jawa Timur, Sumatera Barat, Sulawesi Selatan dan Bali, Yogyakarta: Ombak 